\title{
Seroprevalence of foot-and-mouth disease in large ruminants in periurban dairy farms near Islamabad, Pakistan
}

\author{
Umer Farooq ${ }^{\mathrm{a}}$, Aman Ullah ${ }^{\mathrm{a}}$, Hamid Irshad ${ }^{\mathrm{a}}$, Asma Latifa, Khalid Naeemª, Aamer Bin Zahura, \\ Zaheer Ahmad, ${ }^{\mathrm{a}, \mathrm{b}}$, Luis L. Rodriguez ${ }^{\mathrm{a}, \mathrm{b}}$ \\ ${ }^{a}$ Animal Health Laboratories, Animal Sciences Institute, National Agricultural Research Centre, \\ Park Road, Islamabad 45500, Pakistan \\ ${ }^{b}$ Plum is and Animal Disease Center, Foreign Animal Research Unit, Greenport, NY 11944, USA
}

\begin{abstract}
Background: Foot-and-mouth disease (FMD) is an enzootic viral disease affecting livestock in Pakistan.
Objectives: To determine the seroprevalence of FMD in large ruminants in periurban dairy farms near Islamabad. Methods: Serum samples were collected from 636 large ruminants during 2011 to 2012; 584 (92\%) were buffaloes (Bos bubalis bubalis) and 52 (18\%) were cattle (Bos taurus indicus). The population sampled was mainly adult $(\mathrm{n}=514)$ and female $(\mathrm{n}=596)$. Sera were assayed for antibodies against a nonstructural protein of the FMD virus using a Chekit FMD-3ABC bo-ov enzyme immunoassay Kit (Idexx Laboratories). Data were analyzed using a $\chi^{2}$ test and multiple logistic regression.

Results: The seroprevalence of FMD in the ruminants was 46\% ( $\mathrm{n}=293,95 \%$ confidence interval (CI); 42.18 49.95) and was significantly higher in buffaloes $\left(285,97 \% ; \chi^{2}=21.46 ; P<0.001\right)$ than in cattle $(8,3 \%)$. The risk of seropositivity increased significantly with age $\left(\chi^{2}=72.71 ; P<0.001\right)$; adult animals were 7.05 times more likely (odds ratio (OR) 7.05, 95\% CI 3.60-13.79; $P<0.001$ ) to be seropositive after adjusting for the effect of species. Buffaloes were more likely to be seropositive (OR 3.99, 95\% CI 1.78-8.92, $P=0.001$ ). Sex was not significantly associated with FMD seropositivity (OR 0.58, 95\% CI 0.17-1.95, $P=0.38$ ).

Conclusions: Large ruminants in periurban dairy farms near Islamabad have a high FMD virus seroprevalence and play a potential role in the persistence and transmission of FMD in Pakistan.
\end{abstract}

Keywords: FMD, seroprevalence, buffaloes, cattle, large ruminants, periurban, Pakistan

Foot-and-mouth disease (FMD) is a highly contagious and economically important viral disease of cloven-hoofed ruminants caused by a member of the genus Aphthovirus of the family Picornaviridae. FMD virus (FMDV) exists as seven serotypes (O, A, C, Asia 1, SAT 1, SAT 2, and SAT 3). FMDV replicates rapidly and spreads among ruminants in contact with those infected through aerosols [1]. The disease has a serious impact on the economic condition of farmers and subsequently suppresses agricultural development, altering trade patterns and food security [2]. FMD is enzootic in Pakistan and most of the outbreaks are reported in buffaloes and cattle with prevalent serotypes being $\mathrm{O}, \mathrm{A}$, and Asia-1 [3].

Correspondence to: Umer Farooq, Senior Scientific Officer, Animal Health Laboratories, Animal Sciences Institute, National Agricultural Research Center, Park Road, Islamabad 45500, Pakistan. E-mail: umerfarooq@parc.gov.pk
Disease outbreaks are reported throughout the year [4]. Losses are estimated to be PKR 6.0 billion (USD 100 million) annually (Zulfiqar M. 2003. Draft Report for Development of National Disease Control policy for foot-and-mouth disease in Pakistan under the FAO Project "Support for emergency prevention and control of main trans-boundary animal disease in Pakistan Rinderpest, FMD, PPR”). FMD is an important threat to trade and commodity markets worldwide [5].

FMD in humans is very rare [6]. No cases in humans were reported during the large outbreak of FMD affecting animals in the United Kingdom in 2001, despite increased surveillance [7]. FMD in humans is associated with the consumption of unpasteurized milk, dairy, or unprocessed meat products from infected animals, or as a result of direct contact with infected animals (e.g. in farmers and veterinarians) [8]. To our knowledge, no person-to-person transmission in humans has ever been reported. 
Buffaloes and cattle are an integral part of Pakistan's national herd and their population is 32.7 and 36.9 million, respectively (Pakistan Economic Survey 2014. Edited by Ministry of Finance, Government of Pakistan). Subsequent to acute infection with FMDV these ruminants experience a long persistent asymptomatic infection [1, 9, 10], with continuous circulation of the infective serotype and emergence of new variants [11-13].

The role of carrier animals in the spread of FMD virus is controversial. Evidence for the direct transmission from African buffaloes to cattle in Zimbabwe was reported in 1980 and 1990 [14]. Experimental transmission from buffaloes to cattle has also been documented [14] and it was proposed that transmission occurred through sexual contact between African buffaloes and cattle [15]. The presence of the virus in the esophageal-pharyngeal fluid of cattle indicates that FMDV may be transmitted to other species. The prolonged persistence and replication of FMDV in host animals can lead to genetic variation in the field by generation of new viral variants [16-18].

Antibodies against viral nonstructural proteins (NSP) are produced in animals after the use of impure vaccines or in case of infection [19, 20]. NSP fractions are usually removed from FMDV vaccines during preparation. Therefore, the presence of antibodies to NSP in serum samples, usually indicates ongoing viral activity. Detection of an antibody response to the nonstructural polyprotein 3ABC using enzyme-linked immunosorbent assay (ELISA) seems to be the most reliable indicator of infection. The indirect ELISA used in the present study can detect 3ABC antibodies, the levels of which are higher than other NSPs [21]. The 3ABC ELISA has already been used in ruminants to differentiate between infected and vaccinated animals [23, 24]. Indirect ELISA for FMDV NSP is simple to perform and suitable for large scale serological surveillance in countries like Pakistan.

The objective of the present study was to determine the seroprevalence of antibodies against NSP of FMDV in buffalo and cattle in periurban dairy colonies of large ruminants in Pakistan. The information obtained from the present study would aid in understanding the extent of FMDV circulation in large ruminants under field conditions and the role of these large ruminants in FMD outbreaks.

\section{Materials and methods Samples and sampling area}

Collection of blood samples from animals was approved by the Animal Welfare Committee of the National Agricultural Research Centre, Islamabad (07 October 2010), and the U.S. Department of Agriculture (Project No. 1940-32000-057-58). A crosssectional survey was conducted during 2011-12 of periurban dairy farms near Islamabad. Sample size was calculated using an online sample size tool for cluster surveys available at http://www.micronutrient. org/nutritiontoolkit/ModuleFolders/5.Sampling/tools/ Sample_for_single_cluster_survey_-_persons_per_ HH.htm. A two-stage cluster sampling design was used. A value of 2 for design effect and 25.5\% for estimated prevalence of FMD in large ruminants of Islamabad Capital Territory (ICT) were used to calculate sample size [24]. Using this formula, a total sample size of 600 animals was estimated with 10 animals per household from 60 herds with a 95\% confidence interval (CI) and 5\% precision. This sample size was adjusted for contingency at $5 \%$ to add another 30 samples to increase the sample size to 630 animals. Finally, 64 periurban dairy farms with $\geq 20$ buffalo (Bos bubalis bubalis) and cattle (Bos taurus indicus) were registered at ICT and 636 serum samples were collected from these 64 herds. Ten animals from each farm were bled after documented consent from the farm owners. The blood was collected by jugular vein puncture using an 18-gauge needle and vacutainer tubes (Vacutainer Serum, ref. 367812; BD, Franklin Lakes, NJ, USA). Blood samples were allowed to clot overnight and sera were harvested into labeled $2 \mathrm{~mL}$ cryo vials after centrifugation at $600 \times g$ for 10 minutes. All the sera $(n=636)$ were stored at $-20^{\circ} \mathrm{C}$ until further use. Information regarding the age, sex, breed of animal, vaccination against FMDV, and husbandry practices was recorded in a predesigned recording database.

\section{Detection of FMD virus specific antibodies in sera}

Serum samples were examined for the presence of antibodies against FMD virus NSP using an indirect ELISA (Chekit FMD-3ABC bo-ov EIA Kit, Idexx Laboratories, Westbrook, ME, USA). The assay was performed as described by [25] following the manufacturer's instructions. Briefly, the test sera, and 
positive and negative control sera, were diluted 1:100 with buffer. Diluted sera (100 $\mu \mathrm{L})$ was dispensed in FMDV NSP antigen precoated microtitration plate wells and incubated for $60 \mathrm{~min}$ at $37^{\circ} \mathrm{C}$. After washing the wells, $100 \mu \mathrm{L}$ of anti-ruminant IgG peroxidase conjugate was dispensed into the microtitration plate wells, and incubated for $60 \mathrm{~min}$ at $37^{\circ} \mathrm{C}$. After washing, $100 \mu \mathrm{L}$ of 3,3',5,5'-tetramethylbenzidine chromogenic substrate was added into each well of the microtitration plate. The plate was incubated at room temperature for $15 \mathrm{~min}$ in darkness and then $100 \mu \mathrm{L}$ of stop solution was added into each well. The absorbances of each well were determined using an ELISA plate reader with a $450 \mathrm{~nm}$ filter.

\section{Statistical analyses}

The data obtained were analyzed using a $\chi^{2}$ test and multiple logistic regression.

\section{Results}

The seroprevalence of FMD in the large ruminants in Islamabad Capital Territory was 46\% $(\mathrm{n}=293$, 95\% CI 42.18-49.95). The seroprevalence was significantly $\left(\chi^{2}=21.46 ; P<0.001\right)$ higher in buffaloes $(97 \%, 285)$ than cattle $(8,3 \%)$. The overall seroprevalence of FMD in buffaloes was $49 \%$, while in cattle it was $15 \%$. The number of cattle and buffaloes showing seropositivity for FMDV is shown in Table 1.

The risk of FMD seropositivity increased significantly with age $\left(\chi^{2}=72.71 ; P<0.001\right)$; adult animals were 7.05 times more likely to be seropositive after adjusting for the effect of species (odds ratio (OR) 7.05, 95\% CI; 3.60-13.79; $P<0.001$ ). Buffaloes were more likely to be seropositive for FMD (OR 3.99, 95\% CI; 1.78-8.92, $P=0.001$ ). Age wise distribution of cattle and buffalo is presented in Table 1.
The sex of the animal was not significantly associated with the status of the FMD serology (OR $0.58,95 \%$ CI $0.17-1.95, P=0.38$ ).

\section{Discussion}

Seroprevalence of FMD in buffaloes and cattle in the present study suggests active viral activity. The overall seroprevalence of antibodies against FMDV NSP in large ruminants was $46 \%$. Other studies have similarly reported a high seroprevalence of FMDV NSP antibodies in large ruminants. Kibore et al. [26] reported 52.5\% seroprevalence in cattle in Kenya, Mwiine et al. [27] reported 39.48\% seroprevalence in cattle in Uganda, and Megersa et al. [28] reported 48.1\% seroprevalence in cattle in Ethiopia. By contrast, other workers have found higher and lower FMD seroprevalence in cattle. Olabode et al. [29] reported 75.11\% seroprevalence of FMD in Nigerian cattle, whereas the seroprevalence in Ethiopian cattle in various regions was reported as $21.59 \%$ [30] and 8.01\% [31]. These differences in seroprevalence might be the result of species differences, i.e., cattle rather than buffalo, spatial and temporal variations, and differences in husbandry practices. In Laos, FMD seroprevalence in buffalo was reported as $32.2 \%$, and $26.5 \%$ in cattle [32], which is remarkably lower than in our present study.

Our data suggest that there is a strong association between age of animal and risk of being seropositive for FMD. Similarly, other studies have also found a higher seroprevalence of FMDV NSP antibodies in adult animals than in young animals [26, 29]. Kibore et al. [26] reported higher seroprevalence of FMD in adult cattle ( $>2$ years old) than in calves $<1$ year to 2 years old. A study of Ethiopian cattle found a higher seroprevalence of FMD in adult cattle than in young animals [28]. As the age of the animal increases the chances of exposure to disease increases compared

Table 1. Seroprevalence of foot-and-mouth disease (FMD) in large ruminants in periurban dairy farms in Islamabad Capital Territory

\begin{tabular}{|c|c|c|}
\hline \multirow[t]{2}{*}{ Age group } & \multicolumn{2}{|c|}{ Animals with FMD virus nonstructural protein antibody-positive serum } \\
\hline & Buffalo (Bos bubalis bubalis) & Cattle (Bos taurus indicus) \\
\hline Young & 10/99(10\%) & $4 / 23(17 \%)$ \\
\hline Adult & 275/485(57\%) & $4 / 29(14 \%)$ \\
\hline Total & 285/584(49\%) & $8 / 52(15 \%)$ \\
\hline
\end{tabular}


with young animals who are likely to have less prior exposure [33].

Animals are brought to the periurban dairy colonies of ICT from all over the country, and most animals traveled hundreds of kilometers. There is a possibility that these dairy colonies may act as hub for the persistence and transmission of FMD virus to other areas.

The passage of viruses in susceptible populations may give rise to new variants. Variant information is lacking in the present study. Persistence of FMDV in cattle may generate new variants, which have differences in their viral capsid protein VP1 sequence [16]. To characterize this variation, a study to isolate the FMDV from the animals kept at periurban dairy colonies in Islamabad and to analyze the molecular differences between the viruses is required, and may be useful for vaccine development.

The present study shows the high seroprevalence of FMDV in buffalo and cattle in periurban dairy farms near Islamabad and suggests a role for these large ruminants in the persistent transmission of FMD in Pakistan.

\section{Acknowledgements}

The work described here was supported in part by the Agricultural Research Service, United States Department of Agriculture implemented project No. 1940-32000-057-58, "Characterization of the local isolates of FMD viruses and development of vectorbased vaccines". All authors are salaried employees of the federal Pakistan government. The research described and authorship of the manuscript was all conducted within the duties of the authors' daily work.

\section{Conflict of interest statement}

The authors declare that there is no conflict of interest in this research.

\section{References}

1. Grubman MJ, Baxt B. Foot-and-mouth disease. Clin Microbiol Rev. 2004; 17:465-93.

2. Paton DJ, Sinclair M, Rodriguez R. Qualitative assessment of the commodity risk for spread of footand-mouth disease associated with international trade in deboned beef. Transbound Emerg Dis. 2010; 57:115-34.

3. Jamal SM, Ahmed S, Hussain M, Ali Q. Status of foot-and-mouth disease in Pakistan. Arch Virol. 2010; 155:1487-91.
4. Zahur AB, Irshad H, Hussain M, Anjum R, Khan MQ. Transboundary animal diseases in Pakistan. J Vet Med B Infect Dis Vet Public Health. 2006; 53:19-22.

5. Thompson D, Muriel P, Russell D, Osborne P, Bromley A. Economic costs of the foot-and-mouth disease outbreak in the United Kingdom in 2001. Rev. Sci. Tech. Off. Int. Epiz. 2002;21:675-87.

6. Capella GL, Foot and mouth disease in human beings. Lancet 2001;358:1374.

7. Prempeh H, Smith R, M ller B. Foot and mouth disease: the human consequences. The health consequences are slight, the economic ones huge. BMJ. 2001; 322(7286):565-6.

8. UK Health Protection Agency (HPA), Foot and mouth disease: general information [online]. 2012. [cited 2015 April 01]; Available from: http://webarchive. nationalarchives.gov.uk/20140714084352/http://www. hpa.org.uk/Topics/InfectiousDiseases/Infections AZ/FootAndMouthDisease/GeneralInformation

9. Baxt B, Manson PW. Foot-and-mouth disease virus undergoes restricted replication in macrophage cell cultures following Fc receptor-mediated adsorption. Virology 1995; 207:503-9.

10. Alexandersen S, Zhang Z, Donaldson AI. Aspects of the persistence of foot-and-mouth disease virus in animals - the carrier problem. Microbes Infect. 2002; 4:1099-110.

11. Perez AM, Thurmond MC, Grant PW, Carpenter TE. Use of the scan statistic on disaggregated provincebased data: Foot-and-mouth disease in Iran. Prev Vet Med. 2005;71:197-207.

12. Tosh C, Hemadri D, Sanyal A. Evidence of recombination in the capsid-coding region of type $\mathrm{A}$ foot-and-mouth disease virus. J Gen Virol. 2002; 83: 2455-60.

13. Kesy A. Global situation of foot-and-mouth disease (FMD)—a short review. Pol J Vet Sci. 2002; 5:283-7.

14. Dawe P, Sorensen K, Ferris N, Barnett I, Armstrong R, Knowles N. Experimental transmission of foot-andmouth disease virus from carrier African buffalo (Syncerus caffer) to cattle in Zimbabwe. Vet Rec. 1994; 134:211-15.

15. Bastos AD, Bertschinger JH, Cordel C, van Vuuren CD, Keet D, Bengis RG, et al. Possibility of sexual transmission of foot-and-mouth disease from African buffalo to cattle. Vet Rec. 1999; 145:77-9.

16. Gebauer F, Torre JC dela, Gomes I, Mateu MG, Barahona H, Tiraboschi B, et al. Rapid selection of genetic and antigenic variants of foot-and-mouth disease virus during persistence in cattle. J Virol. 1988; 
62:2041-9.

17. Saiz J, Domingo E. Virulence as a positive trait in viral persistence. J Virol. 1996; 70:6410-3.

18. Toja M, Escarm s C, Domingo E. Genomic nucleotide sequence of a foot-and-mouth disease virus clone and its persistent derivatives: Implications for the evolution of viral quasispecies during a persistent infection. Virus Res. 1999;64:161-71.

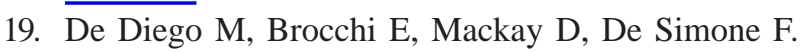
The non-structural polyprotein 3ABC of foot-andmouth disease virus as a diagnostic antigen in ELISA to differentiate infected from vaccinated cattle. Arch Virol. 1997; 142:2021-33.

20. Rodriguez A, Dopazo J, Sáiz JC, Sobrino F. Immunogenicity of non-structural proteins of footand-mouth disease virus: differences between infected and vaccinated swine. Arch Virol. 1994;136: 123-31.

21. S rensen KJ, Madsen KG, Madsen ES, Salt JS, Nqindi J, Mackay DK. Differentiation of infection from vaccination in foot-and-mouth disease by the detection of antibodies to the non-structural proteins 3D, $3 \mathrm{AB}$ and $3 \mathrm{ABC}$ in ELISA using antigens expressed in baculovirus. Arch Virol. 1998; 143:1461-76.

22. Bergmann IE, De Mello PA, Neitzert E, Beck E, Gome I. Diagnosis of persistent aphthovirus infection and its differentiation from vaccination response in cattle by use of enzyme-linked immunoelectrotransfer blot analysis with bioengineered nonstructural viral antigens. Am J Vet Res. 1993; 54:825-31.

23. Mackay DKJ, Forsyth MA, Davies PR, Berlinzani A, Belsham GJ, Flint M. et al. Differentiating infection from vaccination in foot-and-mouth disease using a panel of recombinant, non-structural proteins in ELISA. Vaccine. 1998; 16:446-59.

24. Anjum R, Hussain M, Zahoor AB, Irshad H, Farooq U. Epidemiological analyses of foot-and-mouth disease in Pakistan. Int J Agric Biol. 2006; 8:648-51.
25. Brocchi E, Bergmann IE, Dekker A, Patond DJ, Sammin DJ, Greiner M, et al. Comparative evaluation of six ELISAs for the detection of antibodies to the nonstructural proteins of foot-and-mouth disease virus. Vaccine 2006;24:6966-79.

26. Kibore B, Gitao CG, Sangula A, Kitala P. Foot-andmouth disease sero-prevalence in cattle in Kenya. J Vet Med Anim Heal. 2013; 5:262-8.

27. Mwiine FN, Ayebazibwe C, Olaho-Mukani W, Alexandersen S, Tjornehoj K. Prevalence of antibodies against foot-and-mouth disease virus in cattle in Kasese and Bushenyi districts in Uganda. Int J Anim Vet Adv. 2010; 2:89-96.

28. Megersa B, Beyene B, Abunna F, Regassa A. Amenu K, Rufael T. Risk factors for foot-and-mouth disease seroprevalence in indigenous cattle in southern Ethiopia: The effect of production system. Trop Anim Heal Prod. 2009; 41:891-8.

29. Olabode $\mathrm{OH}$, Kazeem HM, Raji MA, Ibrahim ND. Seroprevalence of foot-and-mouth disease virus antibodies in trade cattle (Bos indicus) in Kwara state of Nigeria. Vet World. 2013; 6: 828-32.

30. Duguma M, Jibril Y, Issa A, Hunde A. Seroprevalence of foot-and-mouth disease of cattle in Bale zone, Oromiya regional state, Ethiopia. Glob Vet. 2013;11: 59-64.

31. Abunna F, Fikru S, Rufael T. Sero-prevalence of footand-mouth disease (FMD) at Dire Dawa and its surroundings, Eastern Ethiopia. Glob Vet. 2013;11: 575-8.

32. Blacksell SD, Khounsy S, Conlan J V, Gleeson LJ. Foot-and-mouth disease in the Lao People's Democratic Republic: II. Seroprevalence estimates, using structured surveillance and surveys of abattoirs. Sci Tech Rev. 2008; 27:851-9.

33. Thrusfield M. Veterinary epidemiology. 3rd ed. Elsevier: New York; 2007. 